\title{
Entrepreneurship and the Economic Theory of the Firm
}

Foss, Nicolai Juul; Klein, Peter G.

Document Version

Final published version

Publication date:

2011

License

CC BY-NC-ND

Citation for published version (APA):

Foss, N. J., \& Klein, P. G. (2011). Entrepreneurship and the Economic Theory of the Firm. University of São Paulo.

Link to publication in CBS Research Portal

\section{General rights}

Copyright and moral rights for the publications made accessible in the public portal are retained by the authors and/or other copyright owners and it is a condition of accessing publications that users recognise and abide by the legal requirements associated with these rights.

\section{Take down policy}

If you believe that this document breaches copyright please contact us (research.lib@cbs.dk) providing details, and we will remove access to the work immediately and investigate your claim. 


\section{CORS - LECTURE}

\section{Entrepreneurship and the economic theory of the firm}

\section{NICOLAI J. FOSS Copenhagen Business School PETER G. KLEIN University of Missouri}

\section{Presented by PETER G. KLEIN}

University of São Paulo

School of Economics, Business and Accounting 


\title{
Working paper
}

\section{ENTREPRENEURSHIP AND THE ECONOMIC THEORY OF THE FIRM}

\author{
Nicolai J. Foss \\ Peter G. Klein
}



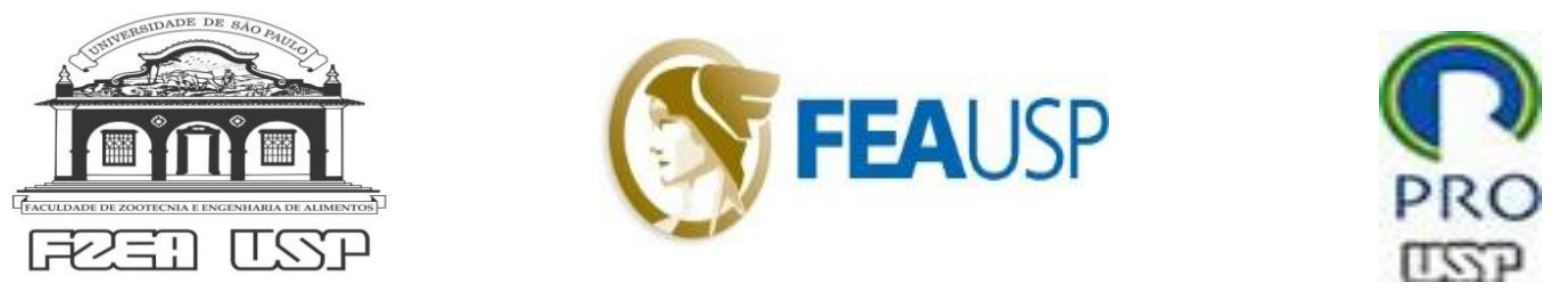

FICHA CATALOGRÁFICA

Elaborada pela Seção de Processamento Técnico do SBD/FEA/USP

Foss, Nicolai J.

Entrepreneurship and the economic theory of the firm / Nicolai J. Foss,

Peter G. Klein. -- São Paulo : FEA/USP, 2011.

50 p. (Cors-Lecture, 1)

Bibliografia.

1. Empreendedorismo 2. Teoria da firma I. Klein, Peter G. II. Universidade de São Paulo. Faculdade de Economia, Administração e Contabilidade.

III. Título. IV. Série.

CDD - 338.04

\section{University of São Paulo \\ School of Economics, Business and Accounting}

Head office: Av. Prof. Luciano Gualberto, 908 - Prédio 1 / Sala C 18 - FEA/USP

Cidade Universitária - São Paulo - SP CEP: 05508-900

Phone numbers: (55-11) 3091-5905; (55-11) 3818-4005

Fax: (55-11) 3818-4017

E-mail: cors@ usp.br

www. cors.ups.br 


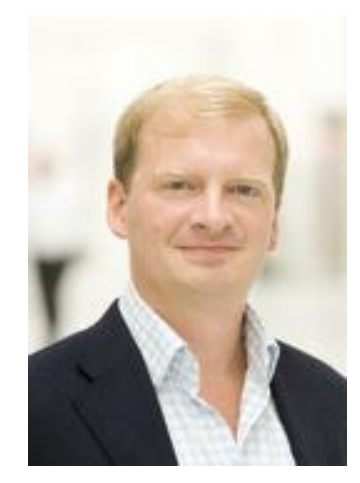

Nicolai J. Foss is a Danish economist, born October 12, 1964. He obtained his $\mathrm{PhD}$ at the Copenhagen Business School. Nicolai J. Foss is a Professor of Strategy and Organization at the Copenhagen Business School (CBS) and the Norwegian School of Economics and Business Administration. It is also an adjunct professor at the universities of Lund and Agder. He directs the Center for Research on CBS strategic management and globalization. His work has been published in major journals of management. Nicolai J. Foss is a specialist in the theory of the firm and strategic management. It is influenced by the approach of Herbert A. Simon, Edith Penrose and school autrichienned'économie. His main research interests concern the theory of management by resources, firm theory and methodology of social sciences.

\section{Professor Foss is also member of the Consultive Board at the CORS.}

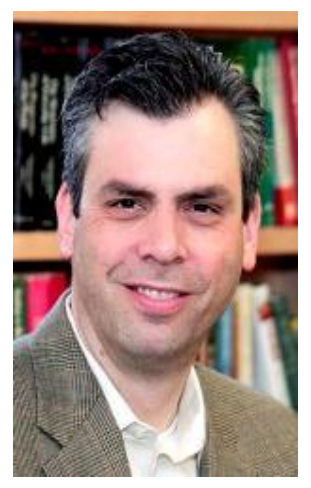

Peter G. Klein is Associate Professor of Applied Social Sciences and Associate Professor of Public Affairs at the University of Missouri Adjunct Professor at the Norwegian School of Economics and Business Administration and Director of the McQuin Center for Entrepreneurial Leadership. His research focuses on the economics of organization, entrepreneurship, and corporate strategy, with applications to diversification, innovation, food and agriculture, economic growth and vertical coordination. Recent courses include $\mathrm{PhD}$ courses in Entrepreneurship, the Economics of Institutions and Organizations, and Industrial Economics, an MBA course in Microeconomics, an M.Sc. course in Network Economics, and undergraduate courses in Business Strategy, the Economics of Managerial Decision Making, Microeconomic Theory, Law and Economics, and Microeconomic Principles. He taught previously at the Olin School of Business, the University of California, Berkeley, the University of Georgia, and the Copenhagen Business School. During the 2000-01 academic year He was a Senior Economist with the Council of Economic Advisers. He blogs on organizations and markets. Professor Klein is also member of the Consultive Board at the CORS. 


\title{
Entrepreneurship and the Economic Theory of the Firm
}

\author{
Nicolai J. Foss \\ Center for Strategic Management and Globalization \\ Copenhagen Business School \\ Porcelainshaven 24B; 2000 Frederiksberg; Denmark \\ njf.smg@cbs.dk \\ and \\ Department of Strategy and Management \\ Norwegian School of Economics and Business Administration \\ Breiviksveien 40, N-5045 \\ Bergen; Norway \\ Peter G. Klein \\ Division of Applied Social Sciences \\ University of Missouri \\ pklein@missouri.edu \\ and \\ Department of Strategy and Management \\ Norwegian School of Economics and Business Administration \\ Breiviksveien 40, N-5045 \\ Bergen; Norway
}

March 2011

To appear as Chapter 6 of Nicolai J. Foss and Peter G. Klein, Organizing Entrepreneurial Judgment: A New Approach to the Firm (Cambridge: Cambridge University Press, 2011). 


\section{Entrepreneurship and the Economic Theory of the Firm}

In Knight's (1921) view, firm organization, profit and loss, and entrepreneurship are inextricably linked. These phenomena arise as an embodiment, a result, and a cause, respectively, of commercial experimentation — a view founded on a particular ontology of the world as essentially open-ended and not deterministic (1921: chapter 7). Few economists have followed Knight in linking the firm, profit and loss, and entrepreneurship, ${ }^{1}$ especially from his philosophical starting points. And yet, as we noted in the beginning of this book, there are many good reasons to treat the theory of entrepreneurship and the theory of the firm together. Such a synthesis informs many foundational questions in economics, business strategy, and public policy: Can we meaningfully address entrepreneurship without considering the organization in which such entrepreneurship takes place? How does the structure of the firm influence entrepreneurial actions? How does firm organization (e.g., the allocation of residual income and control rights) affect the quantity and quality of entrepreneurial ideas? And so on. To answer theses, we need to bring the theory of the firm and entrepreneurship literatures into close contact. And yet, the important connections between these two bodies of literature have been largely overlooked. We seek to identify and establish some of those connections in this and the next two chapters.

In bringing together entrepreneurship and the theory of the firm we hope to convince scholars in both fields that there are significant gains from trade. We start by reviewing extant theory of the firm, asking why these gains were not recognized, evaluated, and exploited. Economics, and hence the economic theory of the firm, developed throughout the twentieth

\footnotetext{
${ }^{1}$ Important exceptions are Barzel (1987), Baumol (1993), and Casson (1997).
} 
century in a particular way, one that effectively excluded the entrepreneur from the organization and the market - not because the insights of Schumpeter, Knight, Mises, and other thinkers on entrepreneurship are unimportant or not subject to clear, precise, systematic presentation and development, but because the increasingly formal and stylized treatment of economic phenomena made it difficult to incorporate judgment and creativity, bounded rationality, unforeseen contingencies, and so on.

We hasten to add that we are not, in this discussion, offering a general critique of modern economics, or tying our call for rehabilitating the entrepreneur's role in economics to some kind of broader reconstruction of the field. On the contrary, the entrepreneur figured prominently in "mainstream" economics until the latter part of the twentieth century, and there is nothing inherently radical or unorthodox in an entrepreneurial theory of the firm and the market. ${ }^{2}$ We shall argue that while the substance of much of modern economics allows for a strong entrepreneurial role, the language of formal economic modeling constitutes a barrier. The more formal game- and information-theoretic versions of the theory of the firm, and, more broadly, the economics of organization, build on assumptions and modeling approaches that effectively exclude the entrepreneur. Nonetheless, we think there are opportunities to generate new theoretical insight and provide better explanations for important phenomena in the theory of the firm from adopting a more entrepreneurial perspective. ${ }^{3}$

\footnotetext{
${ }^{2}$ See Salerno (2009: xxvii-xxxiii) for the case that Murray Rothbard saw his Man, Economy, and State (1962), a founding treatise of the modern Austrian school, as a rehabilita tion of an older mainstream tradition - the neoclassical economics of Wicksteed (1910), Fetter (1910), and Taussig (1911) - rather than a heterodox reconstruction of economic theory. Our aim here is in the same spirit as Rothbard's.

${ }^{3}$ Hence we disagree with Barreto's (1989) claim that entrepreneurship and the theory of the firm inherently cannot be aligned.
} 
Likewise, the entrepreneurship literature can benefit from thinking more carefully and systematically about the organizational environment for, and implications of, entrepreneurship. While modern economics has indeed adopted constraining heuristics, this does not mean that insights from contemporary organizational economics cannot be brought to bear on issues of entrepreneurship. In particular, ideas about property rights, transaction costs, relationshipspecific assets, and the like are very useful for entrepreneurship research, though perhaps expressed differently from the way they appear in mainstream economic treatments. We also make the case for extending these concepts and theories to the entrepreneurship literature. In other words, our aim in this chapter is to encourage cross-fertilization, not one-directional influence.

Research on the theory of the firm has traditionally been organized around the "classic" Coasean (1937) questions of firm emergence, boundaries, and internal organization. Economic organization, then, is about the distribution of transactions across governance structures and mechanisms, and addressing economic organization means explaining why certain governance structures exist, what explains their boundaries vis-à-vis other governance structures, and what (in the case of firms and hybrids) explains their internal organization. We follow this design in the ensuing three chapters.

\section{Entrepreneurship and the theory of the firm: why so little contact?}

\section{The neglect of the entrepreneur by theorists of the firm}

As mentioned in Chapter 1, within the last few decades, the theory of the firm has become one of the fastest growing areas in microeconomics, and has become increasingly influential in management research, though mostly ignored in the entrepreneurship literature (exceptions 
include Jones and Butler, 1992; Mosakowski, 1998; and Alvarez and Barney, 2005). The economic theory of the firm emerged and took shape as the entrepreneur was disappearing from microeconomic analysis, first in the 1930s when the firm was subsumed into neoclassical price theory (O'Brien, 1984), and then in the 1980s as the theory of the firm was reformulated in the language of game theory and the economics of information (e.g., Holmström, 1979; Grossman and Hart, 1986). The gradual "hardening" of the neoclassical approach in economics (see Leijonhufvud, 1968), including the mainstream approach to the theory of the firm, left, little room for the entrepreneurship; Baumol (1993: 17) calls the entrepreneur "the specter which haunts economic models." Indeed, the terms "entrepreneur" and "entrepreneurship" do not even appear in the indexes of leading texts on the economics of organization and management such as Brickley, Smith, and Zimmerman (2008) or Besanko, Dranove, Shanley, and Schaefer (2010). ${ }^{4}$

Similarly, in modern contributions to the theory of the firm (Williamson, 1975, 1985, 1996; Milgrom and Roberts, 1992; Hart, 1995) reference to entrepreneurship is passing at best. (Spulber [2009] is a conspicuous exception.) As we suggested earlier, we do not think this is because the key insights of the economic theory of the firm are somehow irrelevant or cannot be integrated with ideas on entrepreneurship - our claim is quite the opposite. But the specific form in which the economic theory of firm is increasingly cast makes it difficult to put the entrepreneur back in. For example, large parts of contract theory assume that agreements are "complete," meaning that they specify actions or remedies for all possible contingencies, ruling out the possibility of unanticipated contingencies and fundamental uncertainty in contractual

\footnotetext{
${ }^{4}$ Two British surveys of economics principles textbooks (Kent, 1989; Kent and Rushing, 1999) confirm a similar absence of the concept. A review of graduate textbooks used in Sweden (largely the same books used in the US and elsewhere (Johansson, 2004) confirms the absence of the concept of the entrepreneur.
} 
relations. While some aspects of entrepreneurship may be usefully treated in a completecontracting framework (e.g., Kihlström and Laffont, 1979; Lazear, 2005; Barzel, 1987), it flies in the face of the notion, developed in the preceding chapters, that entrepreneurship is exercising judgment about essentially new resource uses in the face of uncertainty (see also Boudreaux and Holcombe, 1989; Langlois and Cosgel, 1993).

\section{The constraining heuristics of the theory of the firm}

The neglect of entrepreneurship in the theory of the firm has much to do with fundamental heuristics for formal modeling. Theorists of the firm, like most other model-builders in mainstream economics, consistently adopt an "on-off" approach in which, for example, agents are either fully informed about some variable or not informed at all, property rights are either perfectly enforced or not enforced at all, actions are either fully verifiable or not verifiable at all, etc. Subtleties are artificial, as in Bayesian models where "the agent knows the true value of $p$ with probability î." Thus, as a modeling convention extreme values are chosen for many choice variables, because some (usually unspecified) information or transaction costs are supposed to prohibit agents from choosing certain actions. Of course, theorists do this to isolate the working of a certain mechanism; for example, how ownership affects investment incentives when it is impossible to contract over investments. The insight derived under extreme conditions, it is argued, may yield insights in investment incentives under less extreme conditions.

But this approach can often lead one astray. Isolating particular mechanisms means suppressing other margins, and thus ignoring entrepreneurship aimed at working around those particular margins. Furubotn (2001: 136) notes, for example, that bounded rationality - a key element of some modern theories of the firm - has important implications for theorizing about the firm: 
[G]iven the cognitive restrictions that constrain each individual and the costly nature of information, a decision maker can have only partial knowledge of the full range of options known to the society as a whole. He can no longer be assumed to know everything about existing technological alternatives, the characteristics and availability of all productive inputs, the existence and true properties of every commodity in the system, etc.

In other words, we cannot reduce the relevant decision problem to combining known inputs into known outputs in a transaction cost minimizing manner (what Kirzner calls "Robbinsian maximizing”). If decision-makers know only a small subset of the many possible input combinations and cannot perfectly foresee future preferences, "the individual devising the firm's policies has to act as a true entrepreneur rather than as a manager routinely implementing clearcut marginal rules for allocation.” (Furubotn, 2001: 139). For this reason, Furubotn argues, transaction costs cannot be the sole cause of governance and contractual choice; overall profitability must be part of the explanation as well.

In this spirit, we review in the remainder of the chapter the dominant established theories of the firm, to show in more detail how existing theory has had difficulties handling entrepreneurship, and to identify insights that are useful for linking entrepreneurship and economic organization. Subsequent chapters flesh out these insights in greater detail.

\section{Established theories of the firm}

\section{The neoclassical theory of the firm}

What is usually termed the "neoclassical" theory of the firm emerged in the 1920s and 1930s in the works of Pigou (1928), Viner (1931), and Robinson (1933, 1934) as a parallel effort 
to the formalization of consumer theory (Hicks and Allen, 1934; Loasby, 1976). (Just as consumers maximize utility subject to a budjet constraint, so firms maximize profit subject to a given production function and input prices.) These writers also sought to make precise Marshall's price-theoretic apparatus, particularly his notion of the "representative firm." It has been argued, however, that the result was something that was very far from Marshall's intentions (Foss, 1994). Indeed, one unfortunate result was that the Marshallian entrepreneur was squeezed out of price theory (Loasby, 1982). The neoclassical production theory underlying the new theory of the firm, with its attendant assumption that all knowledge is exogeneously given blueprint knowledge that is immediately applicable in production, makes the entrepreneur at best a deus ex machina. The theory furnished by Pigou, Viner, and Robinson survives in microeconomics textbooks in the form of the well-known cost apparatus, and it appears-in even more abstract form - in the characterization of producers in competitive general equilibrium models (Debreu, 1959).

In today's economics textbooks, the "firm" is a production function or production possibilities set, a black box that transforms inputs into outputs. The firm is modeled as a single actor, facing a series of decisions that are portrayed as uncomplicated: what level of output to produce, how much of each factor to hire, and the like. These "decisions," of course, are not really decisions at all; they are trivial mathematical calculations, implicit in the underlying data. In the long run, the firm may choose an optimal size and output mix, but even these are determined by the characteristics of the production function (economies of scale, scope, and sequence). In short: the firm is a set of cost curves, and the "theory of the firm" is a calculus problem. There is nothing for an entrepreneur to do. 
While descriptively vacuous, the production-function approach has the appeal of analytical tractability along with its elegant parallel to neoclassical consumer theory (profit maximization is like utility maximization, isoquants are like indifference curves, and so on). Nonetheless, many economists, and most management scholars, find this "production function view" (Williamson, 1985) increasingly unsatisfactory, as unable to account for a variety of real-world business practices: vertical and lateral integration, mergers, geographic and product-line diversification, franchising, long-term commercial contracting, transfer pricing, research joint ventures, and many others. Of course, the theory was never designed to explain such phenomena; it was merely an intermediate step toward explaining market prices (see Machlup, 1967). Still, the silence of the traditional theory of the firm towards questions of comparative economic organization explains much of the recent interest in agency theory, transaction cost economics, the property-rights view, and other approaches that hark back to Coase's landmark 1937 article, "The Nature of the Firm."

\section{Coase}

Coase (1937) introduced a fundamentally new way to think about the firm. In the world of neoclassical price theory, he noted, firms have no reason to exist. If firms emerge in a market economy, he reasoned, it must be that there is a "cost to using the price mechanism" (Coase 1937: 390). Market exchange entails certain costs, such as identifying trading partners, negotiating terms, and writing and enforcing contracts. The "most obvious cost of 'organising' production through the price mechanism is that of discovering what the relevant prices are" (Coase 1937: 390). A second type of cost is that of executing separate contracts for each of the multifold market transactions that would be necessary to coordinate some complex production activity. These costs can be avoided by organizing activities within a firm. Inside the firm, the 
entrepreneur may be able to reduce these "transaction costs" by coordinating these activities himself. However, internal organization brings other kinds of transaction costs, namely problems of information flow, incentives, monitoring, and performance evaluation. The boundary of the firm, then, is determined by the tradeoff, at the margin, between the relative transaction costs of external and internal exchange.

In a single, short paper, Coase laid out the basic desiderata of the economic theory of the firm, namely accounting in a comparative-institutional manner for the allocation of transactions across alternative governance structures. Perhaps the most striking aspect of Coase's article is its programmatic character: Coase calls for a research agenda incorporating incomplete contracts and transaction costs ("the costs of using the price mechanism"), and he argues in favor of a basic contractual conceptualization of the firm and uses an efficiency approach. Most importantly, he defines the main tasks of a theory of the firm, namely to "discover why a firm emerges at all in a specialized exchange economy" (i.e. the existence of the firm), to "study the forces which determine the size of the firm" (i.e., the boundaries of the firm) and to inquire into, for example, "diminishing returns to management" (i.e., the internal organization of the firm. All this, Coase explains, can be reached by incorporating the "costs of using the price mechanism" into ordinary economics. Although terminology and specific insights may differ, most modern theories of the firm are Coasean in the sense that they adhere to this program. But what about the entrepreneur in Coase's thought?

\section{Coase, Knight, and the entrepreneur}

Coase's position on the entrepreneur is somewhat ambiguous. He uses the word, defining the entrepreneur as "the person or persons who, in a competitive system, takes the place of the price mechanism in the direction of resources" (Coase, 1937: 388n), but his "entrepreneur" seems 
to be engaged primarily in the exercise of comparing the costs of organizing given transactions in given governance structures rather than forming judgment under uncertainty, exercising Kirznerian alertness, or being innovative in the Schumpeterian sense. ${ }^{5}$ On the other hand, Coase stresses certain aspects of economic organization that are best understood in the context of entrepreneurial activities. Notably, his discussion of the employment contract makes appeal to unpredictability and the need for qualitative coordination in a world of uncertainty (Langlois and Foss, 1999). This provides ample room for the entrepreneur as a speculating and coordinating agent. However, this potential was not fulfilled, neither in Coase's own thought, nor, as we shall see, in later post-Coasean contribution to the economic theory of the firm.

Coase dismissed Knight's (1921) entrepreneurial explanation of the firm. Arguably, Coase misunderstood Knight (Foss, 1996). Coase criticizes Knight for making the "mode of payment the distinguishing mark of the firm," with entrepreneurs insuring risk-averse workers by assuming full residual claimancy themselves. This can't be a definition of the firm, for Coase, because one "entrepreneur may sell his services to another for a certain sum of money, while the payment to his employees may be mainly or wholly a share in profits" (Coase, 1937: 392). Coase seems to miss that the whole point of Knight's analysis is that the "entrepreneur's services" represent uninsurable risks or genuine uncertainty, and are too costly to trade. (We return to this discussion in the next chapter).

This does not mean that Coase's analysis is opposed to Knight's, however. In some dimensions, the two approaches are complementary. Coase's explanation for the firm's existence, in terms of relative transaction costs, focus on the employment boundaries of the firm. The key

5 This was in keeping with the post-Marshallian tradition of taking "manager" and "entrepreneur" as synonymous (e.g., Kaldor, 1934; Robinson, 1934). Some writers outside the Marshallian tradition, such as Fetter (1905) and Davenport (1914), used words like "enterpriser, "adventurer," and "imprenditor" to distinguish the entrepreneur from the manager. 
distinction for Coase, in other words, is whether the entrepreneur will contract with independent suppliers and distributors or will hire employees. Langlois (2007) argues that Knight does not provide a compelling reason why the entrepreneur-owner must hire employees, so Knight's approach does not constitute a theory of the firm in the Coasean sense. This may be true, but for Knight, the firm is defined in terms of ownership of assets, not employment of people. Knight's theory - like the incomplete-contracting or property-rights view that would emerge in the 1980s and 1990s - focuses on the ownership boundaries of the firm, not the employment boundaries. ${ }^{6}$ Still, Langlois is correct that to explain the use of employees rather than independent contractors as the entrepreneur's associates, a Knightian approach must also incorporate Coasean, transaction cost considerations.

\section{Modern organizational economics}

Lacking the appropriate "analytical technology" that could render his ideas acceptable to mainstream economists, Coase's seminal analysis was neglected for more than three decades. (For a detailed discussion, see Foss and Klein, 2010.) Coase's theory was known and acknowledged, but not used, as Coase (1972) later pointed out. However, at the time of Coase's lamentation, serious work on the theory of firm had begun to take off, thanks to four seminal contributions that defined the central streams of modern research in the theory of the firm:

\footnotetext{
${ }^{6}$ Spulber (2009) defines the firm in terms of Fisher's (1930) "separation theorem," which argues that the neoclassical firm's optimal investment decision is independent of the owner's preferences (and independent of the financing decision). For Spulber (2009: 63), the firm "is defined to be a transaction institution whose objectives differ from those of its owners. The separation is the key difference between the firm and direct exchange between consumers." In our Knightian framework, as in the property rights approach, the firm is defined in terms of asset ownership, not independent preferences - indeed, the owner's preferences represent an ultimate constraint on the firm's activities, even for publicly traded firms. See Hart (2011) for further discussion.
} 
transaction cost economics (Williamson 1971), the nexus-of-contracts view of the firm, (Alchian and Demsetz 1972), agency theory (Ross 1973), and team theory (Marschak and Radner 1972).

Taken together, post-Coasean theories of the firm has followed Coase in conceptualizing the firm as a contractual entity whose existence, boundaries, and internal organization can be rendered intelligible in terms of economizing on (various types of) transaction costs. This is not to say that any one theory in modern organizational economics has addressed all three of these key issues in a unified framework involving the same kind of transaction costs. Instead, there seems to be a division of labor: principal-agent models (Holmström and Milgrom, 1991) and team theory (Marschak and Radner, 1972) are interested mainly in internal organization, while transaction cost economics (Williamson, 1985) and the property rights approach (Hart, 1995; Hart and Moore 1990) deal with firm boundaries. Likewise, these approaches stress different kinds of transaction costs, the with principal-agent models emphasizing monitoring costs, the property rights approach emphasizing costs of writing (complete) contracts, and transaction cost economics focusing on the encforcement and haggling costs that arise after contracts are signed. ${ }^{7}$

Among these approaches, only transaction cost economics and the property rights approach are conventionally seen as theories of the firm per se (Hart, 1995). Principal-agent and team theories deal with productive relationships, but do not address asset ownership; that is, they do not talk about the boundaries of the firm. To explain boundaries, one must presuppose that contracts are incomplete, for otherwise everything can be stipulated contractually and there is no need for ownership, understood as the "residual right" to make decisions that are not specified by contract. Team theory and principal-agent models assume complete contracts, whereas

\footnotetext{
${ }^{7}$ This is a rational reconstruction on our part; formal contract theorists, such as principal-agent or property right theorists, are generally not comfortable with the notion of "transaction cost." See Gibbons (2005) for further discussion.
} 
transaction cost economics and property rights theory work from an incomplete contracting foundations. Accordingly, our main emphasis will be on the latter two approaches.

While the various branches of modern organizational economics contain diverse theories, approaches, and emphases, they share the understanding - sometime implicit - that to explain the raison d'etre of firms, one must move beyond the perfectly competitive model (of Debreu, 1959). This clearly unites all economic theories of the firm Knight (1921) (where the argument is set very clearly out) to Coase (1937) and his transaction cost successors (Williamson, 1996) to modern contract theory (Salanié, 1997; Laffont and Martimort, 2002). While the relevant frictions come in many forms, from (genuine) uncertainty (Knight, 1921), imperfect foresight or bounded rationality (Coase, 1937; Kreps, 1996; MacLeod, 2002), small-numbers bargaining (Williamson, 1996), haggling costs (Coase, 1937), private information (Holmström, 1979), cost of processing information (Marschak and Radner, 1972; Bolton and Dewatripont, 1994), costs of inspecting quality (Barzel, 1982, 1997), or imperfect legal enforcement (Hart, 1995; Williamson, 1996), all these approaches allow deviations from the full, complete, contingent contracting model of perfectly competitive general equilibrium theory (Debreu, 1959).

One result of imperfect contracting is that created value ("welfare," "wealth," "surplus," etc.) falls short of some hypothetical maximum. That first-best situation is taken, however as a benchmark—despite Coase's (1964) and Demsetz's (1969) methodological strictures against this "Nirvana approach." Typically, modern theories of the firm take as the benchmark some notion of the value that would have been created if agents had been interacting in a world entirely free of the sorts of frictions listed above. Such settings may be represented by the conditions underlying the Coase theorem (Coase, 1960) or the First Welfare Theorem of neoclassical economics (Debreu, 1959). Under these conditions maximum value creation obtains; thus, it is 
not possible to rearrange resource uses, coalitions, etc. so that more economic value is produced. Notably, these situations are, to a large extent, institutionally and organizationally neutral, meaning that unconstrained market competition based on privately held property rights will implement the optimal allocation (as will full-scale socialism!). Similarly, whether resources are primarily allocated by firms or by markets does not, strictly speaking, matter for resource allocation. ${ }^{8}$

Of course, such first-best efficiency never obtains in reality, and institutional and organizational arrangements, using different mechanisms for governing inputs, affect the allocation of resources, depending on what is assumed about transactions, property rights, information, and so on. Indeed, a key heuristic underlying all economic theories of the firm is that the relevant units of analysis (transactions, activities, inputs) can be matched to particular alternatives (governance structures such as vertical integration or conctracts) to satisfy some efficiency criterion (what Williamson (1985) calls "discriminating alignment"). It is typically assumed, often using "as if" reasoning, that decision-makers are rational optimizers and that any Pareto-improving (or potential Pareto-improving) changes in alignment between transactions and governance structures will be undertaken (e.g., Milgrom and Roberts, 1992). If agents are unwilling or unable to make these changes, competitive selection forces should still weed out inefficient organizational choices (Williamson, 1985, 1988; Lien and Klein, 2009). (If transition costs prevent adaptation, then the inefficiency may not be "remediable" (Williamson, 1996: ch. 8), and hence the previous alignment is not really inefficient.)

\footnotetext{
${ }^{8}$ Nevertheless, it is usually argued that with perfect and costless contracting, there is no room for anything resembling organizations. Even one-person firms would not exist under such conditions, because consumers could contract directly with owners of factors services and would not need the services of the intermediaries (i.e., firms) (e.g., Cheung, 1983).
} 
The argument that firms emerge when markets for certain transactions or activities "fail," and that organizations are superior means of governing these transactions or activities, does not in itself tell us what mechanisms are involved, and without specifying such mechanisms the argument is simply a tautology. Consequently, a lot of effort has gone into identifying and theorizing the relevant mechanisms. The Leitmotiv of the relevant work over the last three decades has been incentive conflicts emerging from situations like the prisoners' dilemma. ${ }^{9}$ To see incentive conflicts in a market, or, more precisely, small-numbers bargaining context, and how governance can remedy particular kinds of incentive conflicts, consider a simple example.

\section{An example}

The example (which is borrowed from Wernerfelt, 1994) lays out the basic logic of "incomplete contracting" theory, one of the dominant current in organizational economics. The specifics do not automatically translate to other approaches, but the fundamental reasoning and assumptions are quite similar.

Following Hurwicz (1972), one can imagine economic agents choosing game forms, and the resulting equilibria, for regulating their trade. Although the example only highlights two agents (players), "B" can initially be taken as representative of a number of potential agents (e.g., firms) that might want to cooperate with A. That is, "large numbers" conditions obtain, and we can think of the situation as taking place, at least initially, in a market setting.

\footnotetext{
${ }^{9}$ Some work has drawn from team theory (Marschak and Radner, 1972; Aoki, 1986; Radner, 1986; Bolton and Dewatripont, 1994) or started from pure common-interest games (Camerer and Knez, 1996) and has downplayed incentive issues. However, while this approach can further the understanding of those aspects internal organization that relate to information processing, it cannot explain the existence and boundaries of organizations (Williamson 1985; Hart, 1995; Foss, 1996).
} 
Assume that agents initially want to regulate such trade under conditions where they maintain their independence (i.e., they are distinct legal persons). Efficiency requires that agents choose the game form and equilibrium that maximizes the gains from trade. The two players begin by confronting Game 1. In this game, the Pareto criterion is too weak to select a unique equilibrium, since both $\{$ up, left $\}$ and \{down, right $\}$ may be equilibria on this criterion. However, the \{down, right $\}$ equilibrium has a higher joint surplus than the $\{$ up, left equilibrium, so that it will be in A's interest to bribe B to play \{right\}. Surplus maximization suggests that this equilibrium is the agents' preferred one. Their problem then is to design a contract that will make agents choose strategies such these equilibrium choices. Note that this problem captures the spirit of work on specific investments (Klein, Crawford and Alchian, 1978; Williamson, 1985; Hart, 1995) in which an agent (or possibly both agents) has to choose a strategy (in this case $\{$ right $\}$ ) that, while surplus maximizing (when the other agent plays his best-response strategy), is not necessarily attractive to the agent (he only gets 1).

The apparent solution is choose a side-payment, $u$, which can be chosen $(1<u<2)$ to implement the equilibrium where $\mathrm{A}$ plays $\{$ down $\}$ and $\mathrm{B}$ plays $\{$ right $\}$. If the contracting environment is such that this contract can be (costlessly) written and enforced, then agents will choose the efficient strategies. Apparently, there is no need for a firm as defined here, and the small-numbers bargaining situation poses no inefficiency.

However, different contracting environments may give different results. For example, it may be too costly to describe all contract stipulations in a comprehensive manner (e.g., $u$ may be intangible, such as goodwill, and hard to describe precisely). This may be due to information costs, the limitations of natural language, the unavoidable emergence of genuine novelties, and the like. The contract ends up incomplete. Alternatively, the parties may be sufficiently smart to 
write down all the manifold possible aspects of their relationship, but a third party is unable to verify and enforce this agreement (Hart, 1990). Or, the costs of contracting may outweigh the gains (Saussier, 2000). In all these cases, it may not be possible to sustain the first-best outcome, that is, the one that unambiguously maximizes joint surplus. In the context of the example, A may confronted with a contingency that is not covered by the contract, refuse to pay B the bribe, and B may have no recourse. However, B may well have the foresight to anticipate this possibility. Thus, the contract stipulating the side payment may not be sustainable in equilibrium (i.e., the outcome where the agents get $[4-u, 1+u]$ may not be subgame perfect). Value is lower than in the optimal outcome, because B will not rationally choose \{right $\}$.

Whether an efficient or an inefficient outcome occurs will in many situations be critically sensitive to the structure and timing of the game. However, in the specific example, timing doesn't really matter if the contracting environment is such that the promise to transfer $u$ in return for B playing $\{$ right $\}$ is, for whatever reason, unenforceable. Thus, if A gives B the bribe before the game begins, B will not play $\{$ right $\}$, which means that A will decide not to give B any bribe. And if A promises B to pay the bribe after game, B will realize that this will not be in A's interest, and will still play $\{$ left $\}$. This captures the idea that agents who anticipate opportunism on the part of their contractual partner will refrain from taking efficient actions or making efficient investments. The bottom line is that contracts cannot completely safeguard against the reduction of surplus or loss of welfare stemming from incentive conflicts (given risk preferences).

The analytical enterprise is therefore one of comparing alternative contracting arrangements, all of them imperfect (Coase, 1964). A specific contracting arrangement is represented by the authority relation. This obtains when one of the players becomes an 
employee, accepting the other player's orders to play a specific strategy (e.g., $\{$ right $\}$ ) in return for some specified compensation. In other words, the underlying idea is that transferring a transaction or activity from a market to an organization context means that the agreement will be honored. According to Williamson (1985), for example, the reason is a change of incentives: When an agent changes his status from independent entrepreneur to employee, he becomes less of a residual claimant. His incentives to engage in behavior that results in suboptimal equilibria are correspondingly attenuated. In terms of the example, B (or A) may have nothing to gain from playing $\{$ left $\}$ (rather than $\{$ right $\}$ ) once he has assumed employee status, and will therefore obey A's (B's) orders. The law regulating labor transactions may reinforce such "docility" (Masten, 1988), to use Simon's (1991) expression. Or, reputation effects from the ongoing employeremployee relationship may be sufficient to contstrain opportunistic behavior (Kreps, 1996).

\section{The modern theory of the firm and entrepreneurship}

The normal-form game representation shown in the preceding section illustrates a number of the crucial assumptions underlying the modern theory of the firm-assumptions that may not square easily with the phenomenon of entrepreneurship. These are discussed in the following.

\section{Cognition}

Most modern theories of the firm make very strong cognitive assumptions about the cognitive powers of agents. Like virtually all of formal, mainstream economics, these theories assume cognitive homogeneity, correctness, and constancy: agents hold the same, correct, model of the world, and that model does not change. These assumptions are built into formal contract theory (i.e., agency theory and property rights theory) through the assumption that payoffs, 
strategies, the structure of the game, and so on are common knowledge. Bounded rationality is occasionally invoked as a necessary part of the theory of the firm, particularly by Williamson $(1985,1996)^{10}$; but most of the contracting problems studied in the modern theory of the firm require only asymmetric information (Hart 1990). Indeed, bounded rationality seems to serve little function beyond justifying the assumption that contracts are incomplete (Foss, 2001). Likewise, because of the Bayesian underpinning of game-theoretic contract theory, Knightian uncertainty, or any notion of open-endedness or indeterminacy, has no role to play. In the above representation, players can never be surprised. ${ }^{11}$

Clearly, this modeling approach makes little room for entrepreneurship and the characterization of an entrepreneurial market setting that we have described so far. As Phelps (2006: 13) observes:

work on contracts has posited, explicitly or implicitly, that the parties to a contract share identical "rational expectations," since they have the identical model of the world. Work in that vein does not fit in a theory of capitalist economies, in which views are never homogenous and may be wildly diverse.

10 "But for bounded rationality," he argues (1996: 36), "all issues of organization collapse in favor of comprehensive contracting of either Arrow-Debreu or mechanism design kinds." "Comprehensive contracting" does not allow for "governance structures" in the Williamsonian sense of mechanisms that handle the coordination and incentive problems that are produced by unanticipated change (Williamson 1996: chapter 4).

11 Some contributions to contract theory have invoked unanticipated contingencies (e.g., Grossman and Hart, 1986), but such contingencies are never a source of new benefits to the agents, nor do they change the distribution of benefits across agents. Thus, agents are posited to know their final utilities even if unanticipated contingencies impact their trading relationship. For some acerbic comments on this assumption, see Kreps (1996). 
Thus, entrepreneurs may not make optimal use of all available information (Sarasvarthy, 2001), their judgments may be biased (Busenitz and Barney, 1997), and rational expectations simply aren't well-defined under conditions of Knightian uncertainty. ${ }^{12}$

\section{Everything is given}

Because of these strong assumptions about agents' cognitive powers, decision situations are always unambiguous and all decision alternatives are given (Furubotn, 2002). The choice of efficient economic organization is portrayed as a standard maximization problem in the case of contract design or as a choice between given "discrete, structural alternatives" in the case of the choice among governance structures (Williamson 1996). There is no need for experimentation, no learning, and no place for the introduction of novel contractual or organizational forms. In terms of the game-theoretic representation above, strategies and game forms are given, and a host of questions simply are not addressed: How do players come to know the payoffs? Or each other? Or the available strategies? Will they hold the same views of the payoffs? Of each other? Of the available strategies? How do they know which game, and type of game, they are playing $?^{13}$ In the economics of organization (and in most of game theory), these kinds of questions are suppressed by assuming common knowledge: players have identical, shared beliefs

12 As Furubotn (2002: 89) argues, "since Knightian uncertainty prevails, the firm is not in a position to adjust its structure optimally for operation over time. In particular, decision-makers cannot rely on probabilistic calculations ... it can be argued that the New Institutional Economics requires analysis to be very clear in explaining how the boundedly rational entrepreneur makes decisions and acquires information, and in indicating how much information he can reasonably be expected to acquire in any given situation."

13 Obviously, trying to solve this problem by adding a "supergame" in which nature first chooses (with known probabilities) which game the agents are playing, with the agents subsequently acting according to the expected values of the various outcomes, taking nature's prior move into account, simply shifts the problem back a step. How do the agents know the set of possible games among which "nature" can choose? Where do the (typically shared) prior beliefs about the probabilities of various games being played come from? Etc. 
about other players' strategies and these beliefs are consistent with some equilibrium in the game. For some purposes, suppressing ignorance and ill-structured decision situations (Simon, 1973) is entirely legitimate. However, for other purposes, such as understanding the link between entrepreneurship and organization, it is a big problem. ${ }^{14}$

\section{Motivation}

Modern theories of the firm focus on "high-powered" incentives - rewards and punishments that are explicit, measurable, and extrinsic. While not denying that intrinsic motivation plays a role, for instance, in agents' choice of occupation, extrinsic incentives is the main determinant of actions and behaviors on the margin (e.g., the choice of effort, how much to invest in relationship-specific capital, whether to misrepresent information, and so on). Lowerpowered incentives, such as fixed wages, promotions by seniority, or reliance on subjective performance evaluation are used only in situations where high-powered incentives have undesirable side effects - e.g., an agent who works hard in response to a piece rate but shirks on quality. (This problem features prominently in multi-task agency models such as Holmström and Milgrom, 1991). ${ }^{15}$

Today's critics worry about the standard treatment of motivation, not because it assumes opportunism - the bête noire of earlier critics - but because it focuses so strongly on extrinsic motivation (e.g., Osterloh and Frey, 2000). Behavior is almost wholly understood as a response

\footnotetext{
${ }^{14}$ As Loasby (1976: 134) puts it: "The firm exists because it is impossible to specify all actions, even contingent actions in advance; it embodies a very different policy to emergent events. Incomplete specification is its essential basis: for complete specification can be handled by the market."

${ }^{15}$ Benabou and Tirole (2003) try to incorporate intrinsic motivation in the context of an agency model.
} 
to some external force, such as expectation of a tangible. Agents never undertake a task for its own sake. These critics do not necessarily deny the reality of opportunism, moral hazard, and so on, but assert that there are other ways to handle these problems besides reliance on explicit monetary incentives, sanctions, and monitoring. The arguments are often based on social psychology (notably Deci and Ryan, 1985) and experimental economics (e.g., Fehr and Gächter, 2000).

Social psychology research based on "self-determination theory" (Deci and Ryan, 1985) suggests that people have an innate desire for exercising their competences, maintaining a measure of autonomy, and engaging in relationships with other people. Intuitively, these characteristics sound like those that motivate entrepreneurs, and there is indeed some evidence that intrinsic motivation is particularly important to entrepreneurs (e.g., Delmar, 1996; Stenmark, 2000; Guzmán and Santos-Cumplido, 2001; Segal, Borgia and Schoenfeld, 2005; see also Phelps, 2006). This is not to deny, of course, that entrepreneurs pay attention to material rewards (Kirzner, 1982, 1985; Baumol, 1990), particularly on the margin. As we explained in Chapter 4, the entrepreneurial act itself, from the judgment-based perspective, is an intellectual, and not a marginal decision; we do not speak of a supply curve for entrepreneurship as with capital or labor. But within the set of entrepreneurial actions, decisions to invest in one line of business or another, to acquire these or those resources, to write particular contracts or hire particular employees, are affected by marginal rewards and punishments, both extrinsic and intrinsic ( Douglas and Shepherd, 1999). And creative, entrepreneurial efforts inside firms may be particularly driven by intrinsic motivation (Osterloh and Frey, 2000). The neglect of intrinsic motivation in theories of the firm may help explain their uneasy relationship with entrepreneurship. 


\section{Neglect of heterogeneity and capabilities}

Many heterodox economists, notably evolutionary economists, along with strategic management scholars, have criticized the neglect of firm heterogeneity, or differential capabilities, in the theory of the firm (e.g., Winter, 1988; Langlois, 1992). In contrast, they favor a capabilities or "knowledge-based" view of the firm that starts from the empirical generalization that firm-specific knowledge is sticky and tacit and develops through path-dependent processes, implying that organizations are necessarily limited in what they know how to do well. ${ }^{16}$ Much of this work builds on Penrose's (1959) insights about resources, organizational capabilities, and firm growth.

Differential capabilities imply differences in entrepreneurs' abilities to combine and recombine resources efficiently. Skill at exercising entrepreneurial judgment may be considered a capability, and other forms of capabilities may generate Ricardian or Marshallian rents. Beginning perhaps with Langlois (1992), knowledge-based scholars have also argued that the characteristics of capabilities that make them relevant for the study of competitive advantage are also crucial for the main issues in economic organization. Thus, knowledge-based writers argue for a theory of the firm derived from knowledge-based considerations rather than incentives, opportunism, and transaction costs.

We agree with the basic thrust of the critique, that the modern theory of the firm unduly homogenizes what should not be homogenized. And we appreciate the connections between capabilities and knowledge-based views and Austrian ideas about tacit knowledge. ${ }^{17}$ Indeed, in

\footnotetext{
${ }^{16}$ Large parts of the knowledge-based view implicitly and sometimes explicitly subscribe to methodological collectivism (Felin and Foss, 2005).

${ }^{17}$ Several Austrian writers have been particularly attracted to the knowledge-based view as it appears to take seriously the Hayekian notions of tacit, dispersed knowledge and rule-following behavior (Malmgren 1961; O’Driscoll and Rizzo 1985; Loasby 1991; Langlois 1992, 1995,
} 
many ways, the notion that mainly industries matter, and that within-industry differences among firms are relatively unimportant, resembles the portrayal of productive activities based on Shmoo that we criticized in the previous chapter. As Demsetz (1991) points out, much of the modern theory of the firm treats knowledge needed for production as essentially free, while knowledge needed for exchange is costly. Capabilities theories, by contrast, acknowledge that both production and transaction knowledge are costly. In many ways, we clearly side with the capabilities approach in this regard: If capital assets (including knowledge assets) are heterogeneous (chapter 5), the knowledge needed for production should be costly to acquire. Furthermore, if the transaction costs of combining these assets differ across firms (Coase, 1992), firms will grow and develop in different directions. Finally, judgment is obviously heterogeneous across entrepreneurs and different judgment will give rise to different initial resource-assembly in starting a firm and in different boundaries and structures of internal organization as firms grow. For these reason, firms do not possess the same "capabilities."

We thus concur with the capabilities view's emphasis on firm-level heterogeneity. However, an appreciation for heterogeneous capabilities does not mean that contractual considerations are unimportant. Thus, as other researchers have noted (e.g., Silverman, 1999; Nickerson and Zenger, 2004), capabilities and contractual approaches are complements, rather than substitutes; firm-specific knowledge and capabilities affect what an entrepreneur does, but transaction costs may determine how he does it - for instance, whether he works with hired labor

1998; Foss 1997, Foss and Christensen 2001; Dulbecco and Garrouste 1999). Exploring the Austrian roots of capabilities theory has become a virtual cottage industry in recent years. The connection between Penrose and the Austrian school - both indirect and directly through Penrose's dissertation advisor, Mises student Fritz Machlup - has also been examined (Connell, 2007; Foss, Klein, Kor, and Mahoney, 2008). However, these explorations have produced few distinctive insights and refutable implications, limited mainly to exploring similarities between the two bodies of thought. 
or independent contractors, whether he owns or rents his facilities, and so on. We would go farther, however, and argue that entrepreneurial judgment and the transaction costs of resource assembly are antecedents of heterogeneous capabilities. Capabilities emerge as a result of resource assembly and experimentation with asset combinations (see Chapter 5). Thus, entrepreneurial and transaction cost perspectives are logically prior to capabilities.

\section{Neglect of process}

The explanation of economic organization in terms of efficiency and maximization has been a frequent target for critics of the theory of the firm. If agents are boundedly rational, how can they reason through efficient contractual, governance, and organizational arrangements ${ }^{18}$ Moreover, how does the implicit view of the firm as a highly plastic entity, easily reconfigured in response to exogenous shocks, square with more realistic notions of inertia and path dependence? If firms are composed of heterogenous, but complementary capital assets, with entrepreneurial judgment required to determine the best combinations, then firms are formed and reformed as processes of experimentation and learning, not moment-by-moment optimization. According to Winter (1988: 178),

the size of a large firm at a particular time is not to be understood as the solution to some organizational problem. General Motors does not sit atop the Fortune $500 \ldots$ because some set of contemporary cost minimization imperatives (technological or

\footnotetext{
${ }^{18}$ As a first approximation, efficient economic organization is supposed to be consciously chosen by well-informed, rational agents. If pressed on the issue, economists of organization may also invoke evolutionary selection processes. Williamson (1988: 174), for example, notes that applied work in transaction cost economics "relies in a general, background way on the efficacy of competition to perform a sort between more and less efficient modes and to shift resources in favor of the former." Thus, explanation is either fully "intentional" or "functional-evolutionary". See Lien and Klein (2011) for further discussion.
} 
organizational) require a certain chunk of the U.S. economy to be organized in this manner. Its position at the top reflects the cumulative effect of a long string of happenings stretching back into the past.

One way to interpret this critique is that the theory of the firm seeks to explain the governance of individual transactions (Williamson, 1996), or clusters of attributes (Holmström and Milgrom, 1994), without identifying how the governance of a particular transaction depends on governance decisions about other transactions. Argyres and Liebeskind (1999) term this dependency "governance inseparability." In the face of governance inseparability, firms may rely on governance structures that appear inefficient at a particular time, but which make sense as part of a longer-term process. ${ }^{19}$ Changes in governance structure affect not only the transaction in question, but the entire temporal sequence of transactions. This may make organizational form appear more "sticky" than it really is.

These criticisms sound somewhat familiar to Austrian and evolutionary economists, who have long argued for a "process" view of economic activity that takes time seriously (Hayek 1948 Kirzner 1973; Dosi 2000). Hayek (1948) distinguished between the neoclassical economics notion of "competition," identified as a set of equilibrium conditions (number of market participants, characteristics of the product, and so on), and the older notion of competition as a rivalrous process. Practices that appear inefficient or even anticompetitive at a given moment are better understood as part a process of competition through time; it is the process that should be

${ }^{19}$ Governance inseparability refers both to connections between transactions over time, and to connections among transactions within an organization at a moment in time (Argyres, 2010). 
evaluated in welfare terms, not the conditions that obtain at a particular moment in the process (Matsusaka, 2001; Klein and Klein, 2001). ${ }^{20}$

Relatedly, it does not make much sense to cast the entrepreneur in an atemporal setting. Entrepreneurship is not best understood as an instant flash of insight; nor should we compress processes judgment or discovery or innovation into a single Gestalt. These are processes that extend over time, as entrepreneurial conjectures are revised as information is revealed. Moreover, as we argue below, this process understanding of entrepreneurship central to economic organization.

\section{Suppressing margins}

Besides the issues mentioned so far there are other, more subtle reasons for the disconnect between entrepreneurship and the modern theory of the firm. ${ }^{21}$ In the standard models, particularly in contract theory (agency theory and the incomplete-contract approach), assumptions about what agents can do go too far in some respects, while not going sufficiently far in others. Put differently, many theorists of the firm adopt an "on-off" approach to theory building in which, for example, agents are either fully informed about some variable or not informed at all, property rights are either perfectly enforced or not enforced at all, actions are either fully verifiable or not verifiable at all, and so on. ${ }^{22}$ As a modeling convention, extreme

20 Williamson (1996), recognizing the need to incorporate history into transaction cost economics, has introduced the notion of remediableness as a welfare criterion. The outcome of a path-dependent process is suboptimal, he argues, only if it is remediable - that is, an alternative outcome can be implemented with net gains. Merely pointing to a hypothetical superior outcome, if it not attainable, does not establish sub-optimality. This, however, is not a process theory per se.

${ }^{21}$ For a fuller analysis of the issues treated in these paragraphs, see Foss and Foss (2000).

22 This is captured by the notion of "theoretical isolation" that has been developed by Uskali Mäki (1992, 1994), and applied to specific economic debates by Mäki (1999) and Kyläheiko 
values are chosen for many decision variables, with the explanation that some (usually unspecified) information or transaction costs prevent agents from choosing certain actions.

Some of the critiques of the theory of the firm addressed in the preceding section are, in essence, critiques of the arbitrary suppression of certain margins. In othe words, the particular "isolations" chosen in many theories of the firm mean that margins that would be relevant to real-world decision-makers are suppressed. ${ }^{23}$ Notably, agents are not allowed to exercise entrepreneurship to somehow circumvent the interaction problems caused by the suppression of margins (Makowski and Ostroy, 2001).

Perhaps the best known example of the isolation procedures of suppressing margins and entrepreneurship is Keynesianism of the Hicks-Hansen-Modigliani type (what was once called "the neoclassical synthesis"). This type of macroeconomic modeling was designed to produce Keynesian results by introducing arbitrary frictions into an otherwise perfect "classical" model for example, assuming that money wages were rigid downwards (Leijonhufvud, 1968). Indeed, in Hutt's (1939) reading, Keynes produced his results by simply assuming away any optimizing and entrepreneurial behaviors on specific markets, namely labor markets.

Other well-known examples concern the public-good nature of lighthouses (Coase, 1974), the externalities involved in decentralized production of apples and honey (Cheung, 1973), and

(1998). "Isolation" broadly refers to which items are included or excluded in the attempt to comprehend economic reality, something accomplished through "idealizing assumptions." Mäki argues that isolation plays an important role in theoretical disputes in economics, many of which revolve around charges that a given theory isolates too little, too much, or wrongly.

${ }^{23}$ Isolation may be defined the procedure under which "a limited set of items is assumed to be isolated from the involvement or influence of the rest of the world" (Mäki, 1999: 4). As Mäki (1999) further clarifies, along one dimension theoretical isolation may be vertical (i.e., the particularities of items are abstracted away so that something resembling a universal emerges) and/or horizontal (i.e., isolation at a given level of abstraction). Along another dimension, it may be internal (i.e., the system is isolated from influences from within the system) and/or external (i.e., the system is isolated from items outside the system itself). 
the collective goods of fisheries and other non-exclusive resources (Cowen, 1988). In the lighthouse case, the standard argument that lighthouses are pure public goods stemmed from an unexamined assumption that enforcement of property rights for this particular type of good would be prohibitively costly. In contrast, careful consideration of the full set of options available to suppliers of lighthouse services revealed that sufficiently low-cost means of enforcing (at least a significant subset of) the relevant property rights did in fact exist - and were historically employed by alert entrepreneurs (Coase, 1974). ${ }^{24}$ The morale of this story is that categories like "public goods" make sense only within particular arrangements of property rights (Demsetz, 1964; Cowen, 1985) and - more important - these arrangements are endogenous, defined by alert entrepreneurs through contractual innovations, innovations in enforcement methods, and the like (Makowski and Ostroy, 2001). Therefore, neglecting entrepreneurship easily leads to erroneous conclusions about which margins are in play.

Relatedly, modern formal theorists of the firm, such as Hart (1995), suppress margins in order to explain a certain institutional solution (e.g., a certain type of ownership pattern), without considering alternative institutional solutions that may keep interaction problems at bay (e.g., alternative contractual solutions). ${ }^{25}$ As these models are set up, agents are not allowed to surpass the problems caused by suppressed margins by creating new institutional solutions. In other words, entrepreneurship is suppressed. As stated, suppressing margins means prohibiting the agent from knowing or doing certain things within a given interaction structure (typically, by choosing extreme values for some variables); "suppressing entrepreneurship" refers to

24 This is not to say that the British lighthouses were totally private, as Coase's analysis is often thought to have demonstrated. Rather, they were a kind of public-private hybrid in which the properties were privately owned but licensed by the state, and duties were collected under public supervision (Van Zandt, 1993; Bertrand, 2006).

${ }^{25}$ Moreover, to these economists it seems completely legitimate to suppress any margin if it can somehow throw light on some contractual phenomenon. 
prohibiting the agents from going beyond given interaction structures in an attempt to remedy the problems caused by suppressed margins. ${ }^{26}$ Suppressing entrepreneurship implies that agents are not allowed to imagine and implement new institutional solutions, for example to externality problems. Such restrictions imply unexploited profit opportunities (Barzel 1997), but, agents are prohibited from exploiting them as a matter of modeling convention (or lack of imagination on the part of the modeler). In this way, entrepreneurship is suppressed. However, as we argue next, suppressing entrepreneurship is costly, in terms of our understanding of important organizational and strategic phenomena. Incorporating entrepreneurship into the theory of the firm generates substantial insight.

\section{Entrepreneurship as an unrealized potential in the theory of the firm}

\section{Ontological commitments}

Consider the basic view of the economy adopted by both Austrian and new institutionalist writers. In our reading, they stress that economic actors never possess perfect knowledge and that transacting is not costless, but that active, profit-seeking entrepreneurs are continually adjusting and readjusting the economic structure of production in pursuit of profit, including devising new and less costly ways to transact and to acquire information. Now, theorists of the firm may also accept such an ontology, and most likely they do. The real difference lies in the sort of commitments about how economic modeling should be carried out that are believed to flow from such an ontology (O’Driscoll and Rizzo, 1985).

\footnotetext{
${ }^{26}$ This is another way of expressing Kirzner's (1973) distinction, discussed in Chapter 3 above, between "Robbinsian maximizing" - optimizing within a given means-ends framework - and the creation of a new means-ends framework ("entrepreneurship").
} 
On this issue, many positions are possible, and the history of economics witnesses many different ontological commitments. Different extremes are defined by Shackle (1972), who came close to denying the possibility of virtually any modeling for the reason that such modeling would inherently misrepresent the nature of human choice, and Debreu (1959: viii), who from a mathematical formalist point of view stressed that his theory be "logically entirely disconnected from its interpretations." In a highly pertinent context, Barreto $(1989: 115,141)$ argues that:

The confrontation between the basic axioms [of mainstream economics] and the entrepreneur leaves two possibilities: to accept the entrepreneur and reject the modern theory of the firm, or the reject the entrepreneur and maintain allegiance to the modern theory of the firm ... Simply put, entrepreneurship is above "formalization" - it cannot be neatly packaged within a mechanistic, deterministic model. Importantly, the choice is an "either-or" proposition; there is no happy medium. The corner solution, which economic theory has chosen, is consistency, and for this reason the entrepreneur disappeared from economic theory.

While we agree with Barreto's link between the squeezing out of the entrepreneur and the hardening of economics as a research program, we disagree with the drastic conclusion that "there is no happy medium." Our critique of the modern theory of the firm does not concern all of its basic insights and constructs; rather, we are concerned mainly with the specific form that these insights and constructs take. For example, while modern contract theory uses specific game-theoretic (Bayesian) equilibrium concepts that assume that coordination takes place by means of pure ratiocination, ${ }^{27}$ this is a specific form in which more fundamental, "intuitive"

\footnotetext{
${ }^{27}$ Thus, agents are assumed to be able to coordinate on any desired game form and equilibrium thereof, subject to constraints such as attitudes to risk, incentive trade-offs, bargaining power, and asymmetric information.
} 
insights are cast for the purposes of ease of mathematical modeling and tractability; it is not essential to the theory as such.

\section{Putting entrepreneurship into the theory of the firm}

In a number of ways, modern organizational economics applies an analytical apparatus that is potentially capable of illuminating important aspects of entrepreneurship, particularly the judgment-based view we are developing here. For example, the emphasis on asset ownership in TCE and the property rights view as a crucial aspect of firm organization accords well with Knight's (1921) and Mises' (1949) views. So does the emphasis on incomplete contracting. And notions of asymmetric information help to illuminate what is distinctive about entrepreneurship relative to other kinds of decision-making. Still, the modern economics of organization is in many ways a direct descendant of the neoclassical theory of the firm that it supplanted. For example, as capabilities theorists have pointed out, the modern economics of organization has not made a break with the neoclassical theory of production, but merely a grafted super-structure of asymmetric information, transaction costs, and other "frictions" onto the neoclassical theory (Langlois and Foss, 1999). Moreover, the modern economics of organization has the same deterministic and "closed" feel as the neoclassical theory of the firm: although notions of uncertainty, ignorance, and surprise are occasionally invoked in, these serve mainly as rhetorical devices to justify the assumption of contractual incompleteness (Foss 2003). Such notions are not themselves addressed, explained, and explored, and they are certainly not invoked to make room for process and entrepreneurship. Still, key insights from organizational economics may be usefully applied to an extended theory of economic organization, one that makes room for entrepreneurial judgment. 
Specifically: An entrepreneur needs to transact with other agents - owners of heterogeneous physical and human capital - to realize his judgment as embodied in a business plan, or, more narrowly, a business model. ${ }^{28}$ The relevant transactions can be organized by multiple contractual institutions. Transaction cost economics therefore seems to be wellpositioned to shed light on the economic organization of key aspects entrepreneurship, notably how an can entrepreneur safeguard his investments into a business plan against the appropriation by other contracting parties. Williamson's $(1985,2000)$ simple contracting schema suggests that contracting parties match the governance mode to the transaction attributes to safeguard investments. The entrepreneur becomes tied to a resource coalition if the investment into a business plan is relationship-specific. The exploitation of the business idea then requires access to other resources, leading to bilateral or multilateral dependency between contracting parties. Dependency not only increases the need for continuous adaptation, but also creates a possible hold-up situation for the entrepreneur. Other resource owners may block the pursuit of the business idea, unless they receive a larger share of the generated income. Thus, the entrepreneur must also decide on contractual safeguards to protect entrepreneurial returns in designing the business model.

Human agents may be boundedly rational, but, in the transaction cost perspective, they are far from myopic in designing a business model. Rather, contracting is assumed to be far-sighted (Williamson, 1996; Williamson, 2000; see Foss, 2001). When entering a contractual relationship, the parties consider possible contractual hazards that may emerge and try to structure the safeguards accordingly. Without safeguards, a contracting party may be reluctant to invest into

${ }^{28}$ We are using the term "human capital" here loosely, in the conventional sense of valuable knowledge, skills, experience, etc., while recognizing that human capabilities are not, strictly speaking, "capital," as they do not exist as discrete, marginal units that can be bought and sold and priced, the way a factory or a machine or a piece of land can be exchanged in a market. 
specific assets, since it may suffer from the holdup problem after making the investment. Thus, an entrepreneur may be keenly aware of problem of safeguarding possible entrepreneurial gains before devoting resource to researching and developing a business idea. He will attempt to protect himself against opportunism by others and structure the business model around these hazards.

However, transaction cost economics does not assume that there always is an optimal match between transaction characteristics and contractual safeguards (Williamson, 1985). Contracting parties may fail to identify a hazard when entering a relationship; safeguards may not work effectively. Disappointments are bound to happen. Appropriate safeguards may emerge only over time, as parties learn from their mistakes (Mayer and Argyres, 2004; Argyres and Mayer, 2007.) Thus, contracting may be farsighted, but it is far from perfect or comprehensive. Contracting partners do not form rational expectations of the (net) benefits (utilities) that may flow from a relation (Kreps, 1996), although they can be assumed to form rough estimates and "confidence intervals" of these. Viewed from this angle, the simple contracting schema offers a process perspective on economic organization. It suggests that how a given transaction is governed may change over time, as the contracting parties learn and adapt the modes of governance (Furubotn, 2006). In turn, contracting partners may revise their estimates of such benefits. These actions are manifestations of entrepreneurship. Such straightforward application of a key organizational economics theory suggests the potential fruitfulness in linking established work in this broad research stream to ideas about entrepreneurial judgment. ${ }^{29}$

${ }^{29}$ While the simple contracting schema suggests a comparative-static, optimization approach, Williamson has always emphasized the process aspects of economic organization through his emphasis on adaptation. The choice between "market" and "hierarchy" can be seen as the choice among mechanisms to facilitate particular types of adaptation: decentralized, market governance supports "autonomous" adaptation, while the key advantage of internal organization is its ability 


\section{Existing attempts at integration}

We are not the first to call for a closer integration between the theory of entrepreneurship and the theory of the firm, though our approach is more "mainstream" than most, as we build primarily on contractual, rather than capabilities, views of organization. As Langlois (2007) points out, the

existing literature consists of two types of studies: "entrepreneurial theories of the firm" and "theories of the entrepreneurial firm." The latter category includes most of the extant literature, and focuses on the economic organization of new ventures. Much of the literature on venture capital and the contractual relationships between venture capitalists and firm founders (Gompers, 1995; Kaplan and Stromberg, 2003) can be considered part of this literature.

Our approach, by contrast, falls into the former category; that is, we seek to show how concepts of the entrepreneurial function (in the sense described in chapter 2 above) can be incorporated into economic and managerial theories of the firm. Other scholars have built on the resource-based and knowledge-based theories of the firm to argue that particular firm capabilities should be understood in an entrepreneurial context. Langlois and Robertson (1995), for example, conceive the firm's "dynamic capabilities" as its ability to respond to opportunities for rent creation in a changing landscape - a sort of firm-level version of Kirznerian alertness. Kor, Mahoney, and Michael (2007) focus on Penrose's (1959) concept of the firm's "productive opportunity set," explaining how the set of opportunities facing the firm is not given, exogenously, but created through team dynamics and other organizational attributes, attributes which can be interpreted as entrepreneurial characteristics (see also Foss, Klein, Kor and Mahoney, 2008). Witt's

to effect "bilateral" adaptation (Williamson, 1991b: 163-64). See also Gibbons (2005) for the case that there are two theories of the firm in Williamson's writings, the asset specificity and hold-up theory associated with Williamson and Klein, Crawford, and Alchian (1978) and a distinct adaptation theory that receives greater emphasis in Williamson's earlier work. 
(1998a, 1998b, 2007) theory of entrepreneurship as cognitive leadership, described in Chapter 2, represents another way to link entrepreneurship to organizational design. However, as we noted above, the leadership approach helps us understand what teams do, but does not explain how these activities should be structured, contractually. Diffuse networks, such as open-source communities, members of professional associations, and the like share many of the characteristics of Witt's cognitive teams, but do not share ownership of tangible assets or relate through each other through employment contracts. Understanding the boundaries of the firm per se requires some kind of contractual explanation.

\section{Conclusions}

In summary, while various economists and management scholars have suggested links between the economics of the firm and entrepreneurship (Foss, 1993; Langlois and Cosgel, 1993; Casson, 1997; Foss and Klein, 2005; Alvarez and Barney, 2007), analysis of these links are few, highly preliminary, and mainly based on ideas on capabilities and resources rather than on the more mainstream, Coasean, contractual approach to the firm. We suspect that entrepreneurship scholars and "heterodox" organizational economists have been turned off by the formal, static, "closed" characteristics of contractual theories that seem to have little room for entrepreneurship and bounded rationality, ignore the possibility that mental models differ across entrepreneurs, emphasize risk rather than Knightian uncertainty, and treat opportunity discovery as solely a function of past learning and experience. Large parts of the modern theory of the firm (transaction cost economics excepted) rest on game theory (Gibbons, 1999), which seems particularly unsuited for exploring these broader issues. 
We share many of these frustration with modern, "mainstream," contractual approaches to the firm. However, we see much potential for incorporating entrepreneurship into the contractual approach. ${ }^{30}$ This is further pursued in the following two chapters.

\section{References}

Alchian, Armen A., and Harold Demsetz. 1972. "Production, Information Costs, and Economic Organization." American Economic Review 62(5): 777-95.

Alvarez, Sharon A., and Jay B. Barney. 2005. "How do Entrepreneurs Organize Firms under Conditions of Uncertainty." Journal of Management 31(5): 776-93.

Alvarez, Sharon A., and Jay B. Barney. 2007. "Discovery and Creation: Alternative Theories of Entrepreneurial Action." Strategic Entrepreneurship Journal 1(1-2): 11-26.

Amabile, Teresa M. 1997. "Motivating Creativity in Organizations: On Doing What You Love and Loving What You Do." California Management Review 40(1): 39-58.

Aoki, Masahiko. 1986. Horizontal vs vertical information structure of the firm, American Economic Review, 76,971 $-983$.

Argyres, Nicholas S., and Julia Porter Liebeskind. 1999. "Contractual Commitments, Bargaining Power, and Governance Inseparability: Incorporating History into Transaction Cost Theory." Academy of Management Review 24(1): 49-63.

Argyres, Nicholas S., and Kyle J. Mayer, 2007. "Contract Design as a Firm Capability: An Integration of Learning and Transaction Cost Perspectives." Academy of Management Review 32: 1060-77.

Argyres, Nicholas. 2010. "The Transaction as the Unit of Analysis." In Peter G. Klein and Michael E. Sykuta, eds., The Elgar Companion to Transaction Cost Economics. Cheltenham, U.K.: Edward Elgar: 127-32.

Barreto, Humberto 1989. The Entrepreneur in Microeconomic Theory: Disappearance and Explanation, Routledge and Kegan Paul.

Barzel, Yoram. 1982. "Measurement Cost and the Organization of Markets." Journal of Law and Economics 25(1): $27-48$.

Barzel, Yoram. 1987. “The Entrepreneur's Reward for Self-Policing.” Economic Inquiry 25: $103-16$.

Barzel, Yoram. 1997. Economic Analysis of Property Rights. 2nd ed., Cambridge: Cambridge University Press.

Baumol, William J. 1990. "Entrepreneurship: Productive, Unproductive, and Destructive." Journal of Political Economy 98(5): 893-921.

${ }^{30}$ Our approach builds heavily on aspects of Austrian economics, capital theory in particular, yet Austrian economists have usually been suspicious of the Coasean approach to the firm. O’Driscoll and Rizzo (1985: 124), while acknowledging Coase's approach as an "excellent static conceptualization of the problem," argue that a more evolutionary framework is needed to understand how firms respond to change. Boudreaux and Holcombe (1989) and Langlois (1995) take a similar position. However, as noted above, the closed ontology associated with mainstream organizational economics is not necessarily incompatible with the more "open" ontology favored by Austrians. 
Baumol, William J. 1993. Entrepreneurship, Management and the Structure of Pay-Offs. Cambridge, Mass.: MIT Press.

Becarra, M. 2009. Theory of the Firm for Strategic Management. Cambridge: Cambridge University Press.

Benabou, Roland, and Jean Tirole. 2003. "Intrinsic and Extrinsic Motivation." Review of Economic Studies, 70(3): 489-520.

Bertrand, Elodie. 2006. "The Coasean Analysis of Lighthouse Financing: Myths and Realities." Cambridge Journal of Economics 30(3): 389-402.

Besanko, David, David Dranove, Mark Shanley, and Scott Schaefer. 2010. Economics of Strategy. $3^{\text {rd }}$ ed. John Wiley.

Bolton, Patrick and Mathias Dewatripont. 1994. "The Firm as a Communication Network." The Quarterly Journal of Economics 109(4): 809-39.

Boudreaux, Donald J., and Randall G. Holcombe. 1989. "The Coasian and Knightian Theories of the Firm." Managerial and Decision Economics 10(2): 147-54.

Brickley, James A., Clifford W. Smith, and Jerold L. Zimmerman. 2008. Managerial Economics and Organizational Architecture. Irwin: Fifth edition, New York: McGraw-Hill.

Busenitz, Lowell W. and Jay B. Barney. 1997. "Differences between Entrepreneurs and Managers in Large Organizations: Biases and Heuristics in Strategic Decision-Making." Journal of Business Venturing 12(1): 930.

Camerer, C. and Knez, M. 1996. Coordination: organization boundaries and fads in business practice, Industrial and Corporate Change, 5, 89-112.

Casson, Mark. 1997. Information and Organization. Oxford: Oxford University Press.

Cheung, Steven N. S. 1973. "The Fable of the Bees." Journal of Law and Economics 16: 11-34.

Cheung, Steven N. S. 1983. "The Contractual Nature of the Firm.” Journal of Law and Economics 26(1): 1-21.

Coase, Ronald H. 1937. "The Nature of the Firm.” Economica 4: 386-405.

Coase, Ronald H. 1960. "The Problem of Social Cost." Journal of Law and Economics 3(1): 1-44.

Coase, Ronald H. 1964. "The Regulated Industries: Discussion.” American Economic Review 54(3): 194-97.

Coase, Ronald H. 1972. "Industrial Organization: A Proposal for Research." In Policy Issues and Research Opportunities in Industrial Organization, ed. V. R. Fuchs, 59-73. New York: National Bureau of Economic Research.

Coase, Ronald H. 1974. "Lighthouse in Economics, The." Journal of Law and Economics 17(2): 357-76.

Coase, Ronald H. 1992. "The Institutional Structure of Production.” The American Economic Review 82(4): 713-19.

Connell, Carol Matheson. 2007. "Discerning a Mentor's Role: The Influence of Fritz Machlup on Edith Penrose and the Theory of The Growth of the Firm." Journal of Management History 13(3): 228-239.

Cowen, Tyler. 1988. The Theory of Market Failure: A Critical Examination. Fairfax, Va.: George Mason University Press.

Cowen, Tyler. 1985. Public goods definitions and their institutional context: a critique of public goods theory, Review of Social Economy, 43, 53-63.

Davenport, Herbert J. 1914. Economics of Enterprise. New York: Macmillan.

Debreu, Gerard. 1959. Theory of Value. New York: Wiley.

Deci, Edward L. and Richard M. Ryan. 1985. Intrinsic Motivation and Self-Determination in Human Behavior, Springer.

Delmar, Frédéric. 1996. Entrepreneurial behavior and business performance. Ekonomiska forskningsinstitutet vid Handelshogskolan i Stockholm. 
Demmert, Henry and Daniel B. Klein. 2003. "Experiment on Entrepreneurial Discovery: An Attempt to Demonstrate the Conjecture of Hayek and Kirzner." Journal of Economic Behavior and Organization 50(3): 295-310.

Demsetz, Harold. 1964. "The Exchange and Enforcement of Property Rights." Journal of Law and Economics 7: 11-26. In idem. 1988. Ownership, Control, and the Firm. Oxford: Basil Blackwell.

Demsetz, Harold. 1969. "Information and Efficiency: A Different Viewpoint." In Demsetz, Ownership, Control, and the Firm. Oxford: Basil Blackwell, 1988.

Demsetz, Harold. 1991. "The Theory of the Firm Revisited." In Oliver E. Williamson and Sidney G. Winter, eds. 1991. The Nature of the Firm, Oxford: Blackwell.

Douglas, Evan J. and Dean A. Shepherd. 1999. "Entrepreneurship as a Utility Maximizing Response." Journal of Business Venturing 15(3): 231-51.

Elfenbein, Daniel W., Barton H. Hamilton, and Todd R. Zenger. 2010. "The Small Firm Effect and the Entrepreneurial Spawning of Scientists and Engineers." Management Science 56: 1-23.

Fehr, Ernst, and Simon Gächter. 2000. "Cooperation and Punishment in Public Goods Experiments." The American Economic Review 90(4): 980-994.

Felin, Teppo, and Nicolai J. Foss. 2005. "Strategic Organization: A Field in Search of Micro-Foundations." Strategic Organization 3(4): 441.

Fetter, Frank A. 1905. The Principles of Economics. New York: The Century Co.

Fetter, Frank A. 1910. The Principles of Economics, with Applications to Practical Problems. New York: Century.

Fisher, Irving. 1930. The theory of interest, Macmillan, New York.

Foss, Kirsten. 2001. "Organizing Technological Interdependencies: A Coordination Perspective on the Firm." Industrial and Corporate Change 10(1): 151-78.

Foss, Kirsten, and Nicolai J. Foss. 2000. "Theoretical Isolation in Contract Economics." Journal of Economic Methodology 7: 313-339.

Foss, Nicolai J. and Klein, Peter G. 2010. Alertness and antecedents of Entrepreneurship. Working Paper, SMGWPStrategic management and Globalization Copenhaguem Business School, Mar. 2010.

Foss, Nicolai J. 1993. "Theories of the Firm: "Contractual and Competence Perspectives." Journal of Evolutionary Economics 3: 127-44.

Foss, Nicolai J. 1994. 'The Biological Analogy and the Theory of the Firm: Marshall and Monopolistic Competition.' Journal of Economic Isssues 28: 1115-136.

Foss, Nicolai J. 1994. "Realism and Evolutionary Economics". Journal of Social and Biological Systems 17: 21-40.

Foss, Nicolai J. 1996a. "Knowledge-Based Approaches to the Theory of the Firm: Some Critical Comments". Organization Science 7: 470-476 (1996).

Foss, Nicolai J. 1996b. "The "Alternative" Theories of Knight and Coase, and the Modern Theory of the Firm". Journal of the History of Economic Thought, 18: 76-95 (1996).

Foss, Nicolai J. 1999. "The Use of Knowledge in Firms." Journal of Institutional and Theoretical Economics 155: 458-486.

Foss, Nicolai J. 2003. "Selective Intervention and Internal Hybrids: Interpreting and Learning from the Rise and Decline of the Oticon Spaghetti Organization." Organization Science 14: 331-349 (2003).

Foss, Nicolai J., and Jens Frøslev Christensen. 2001. "A Market-Process Approach to Corporate Coherence." Managerial and Decision Economics 22(4-5): 213-26.

Foss, Nicolai J., and Peter G. Klein. 2005. "Entrepreneurship and the Economic Theory of the Firm: Any Gains from Trade?" In Rajshree Agarwal, Sharon A. Alvarez, and Olav Sorenson, eds., Handbook of Entrepreneurship Research: Disciplinary Perspectives. Dordrecht: Springer. 
Foss, Nicolai J., and Peter G. Klein. 2010. "Alertness, Action, and the Antecedents of Entrepreneurship." Journal of Private Enterprise 25: 145-64.

Foss, Nicolai J., Peter G. Klein, Yasemin Y. Kor, and Joseph T. Mahoney. 2008. "Entrepreneurship, Subjectivism, and the Resource-Based View: Towards a New Synthesis." Strategic Entrepreneurship Journal 2(1): 73-94.

Furubotn, Erik G. 2001. "The New Institutional Economics and the Theory of the Firm." Journal of Economics Behavior and Organization 45(2): 133-53.

Furubotn, Eirik G. 2002. "Entrepreneurship, Transaction-Cost Economics, and the Design of Contracts." In The Economics of Contracts: Theories and Applications, ed. É. Brousseau and J.-M. Glachant, 72-97. Cambridge: Cambridge University Press.

Furubotn, Eirik G. 2006. "The New Institutional Economics and the Theory of the Multiobjective Firm." In Institutions in Perspective: Festschrift in Honor of Rudolf Richter on the Occasion of His 80th Birthday, ed. R. Richter, U. Bindseil, J. Haucap and C. Wey, 37. Thüringen: Mohr Siebeck.

Gibbons, Robert. 1999. “Taking Coase Seriously,” Administrative Science Quarterly, 44: 145-157.

Gibbons, Robert 2005. "Four Formal(izable) Theories of the Firm." Journal of Economic Behavior and Organization 58: 200-45.

Gompers, Paul A. 1995. "Optimal Investment, Monitoring, and the Staging of Venture Capital." The Journal of Finance 50(5): 1461-489.

Grossman, Sanford J., and Oliver D. Hart. 1986. 'The Costs and Benefits of Ownership: A Theory of Vertical and Lateral Integration.’ Journal of Political Economy 94: 691-719.

Guzmán, Joaquín, and F. Javier Santos 2001. "The Booster Function and the Entrepreneurial Quality: An Application To The Province Of Seville." Entrepreneurship and Regional Development 13: 211-28.

Hart, Oliver D. 1990. “Is 'Bounded Rationality' an Important Element of a Theory of Institutions?” Journal of Institutional and Theoretical Economics 16: 696-702.

Hart, Oliver D. 1995. Firms, Contracts, and Financial Structure. Oxford: The Clarendon Press.

Hart, Oliver. 2011. "Thinking about the Firm: A Review of Daniel Spulber's The Theory of the Firm." Journal of Economic Literature 49(1): 101-13.

Hart, Oliver and John Moore. 1990. "Property Rights and the Nature of the Firm." Journal of Political Economy 98 (6): 1119-158.

Hayek, F. A. 1948. Individualism and Economic Order. Chicago: University of Chicago Press.

Hicks, John R. and R.G.D. Allen. 1934. “A Reconsideration of the Theory of Value.” Economica 1(1): 52-76.

Holmström, Bengt. 1979. "Moral Hazard and Observability." The Bell Journal of Economics 10(1): 74-91.

Holmström, Bengt and Paul R. Milgrom. 1991. "Multitask Principal-Agent Analysis: Incentive Contracts, Asset Ownership and Job Design.” Journal of Law, Economics and Organization 7: 24-54.

Holmström, Bengt and Paul R. Milgrom. 1994. "The Firm as an Incentive System.” The American Economic Review 84(4): 972-91.

Hurwicz, Leonid. 1972. “On Informationally Decentralized Systems.” In Charles B. McGuire and Roy Radner, eds., Decision and Organization. Amsterdam: North Holland: 297-233

Hutt, William H. 1939. The Theory of Idle Resources, J. Cape.

Johansson D. 2004. "Economics without Entrepreneurship or Institutions: A Vocabulary Analysis of Graduate Textbooks.” Econ Journal Watch: 515-538.

Jones, G. R., and J. E. Butler. 1992. "Managing Internal Corporate Entrepreneurship: An Agency Theory Perspective." Journal of Management 18(4): 733-749.

Kaldor, Nicholas. 1934. “The Equilibrium of the Firm.” The Economic Journal 44(173): 60-76. 
Kent, C. A. 1989. "Coverage of Entrepreneurship in Principles of Economics Textbooks." Journal of Economic Education 20: 153-64.

Kent, C. A. and Rushing, F. W. 1999. "Coverage of Entrepreneurship in Principles of Economics Textbooks: An Update.” Journal of Economics Education 30(2): 184-88

Keynes, John Maynard. 1937. The General Theory of Employment, Quarterly Journal of Economics, 51: 209-223.

Kihlstrom, Richard E., and Jean-Jacques Laffont. 1979. "A General Equilibrium Entrepreneurial Theory of Firm Formation Based on Risk Aversion.” Journal of Political Economy 87, no. 4: 719-748.

Kirzner, Israel M. 1973. Competition and Entrepreneurship. Chicago: University of Chicago Press.

Kirzner, Israel M. 1982. "Competition, Regulation, and the Market Process: An 'Austrian' Perspective.” Cato Policy Analysis 18.

Klein, Benjamin, Robert A. Crawford and Armen A. Alchian. 1978. "Vertical Integration, Apropriable Rents, and the Competitive Contracting Process." Journal of Law and Economics 21(2): 297-326.

Klein, Peter G. and Sandra R. Klein. 2001. Do entrepreurs make predictable mistakes? Evidence from Corporate divestitures, Quarterly Journal of Austrian Economics, 4, 3-25.

Knight, Frank H. 1921. Risk, Uncertainty, and Profit. New York: August M. Kelley.

Knight, Frank H. 1936. "The Quantity of Capital and the Rate of Interest." Journal of Political Economy 44: 433$463,612-642$.

Kor, Yasemine Y.; Joseph T. Mahoney and S.C. Michael. 2007. "Resources, Capabilities and Entrepreneurial Perceptions*." Journal of Management Studies 44(7): 1187-212.

Kreps, D. M. 1996. "Markets and Hierarchies and (Mathematical) Economic Theory", Industrial and Corporate Change 5: 561-595.

Kyläheiko, K. 1998. "Making Sense of Technology: Towards a Synthesis between Neoclassical and Evolutionary Approaches." International journal of production economics 56: 319-332.

Laffont, Jean-Jacques and David Martimort. 2002. The Theory of Incentives: The Principal-Agent Model, Princeton, NJ: Princeton University Press.

Langlois, Richard N. 1992. "Transaction Cost Economics in Real Time." Industrial and Corporate Change 1(1): 99-127.

Langlois, Richard N. 1995. "Capabilities and Coherence in Firms and Markets." In Cynthia A. Montgomery, ed., Resource-based and Evolutionary Theories of the Firm: Towards a Synthesis. Dordrecht: Kluwer Academic Publishers: $71-100$.

Langlois, Richard N. 1998. "Personal Capitalism as Charismatic Authority: The Organizational Economics of a Weberian Concept." Industrial and Corporate Change 7: 195-213.

Langlois, Richard N. 2007. "The Austrian Theory of the Firm: Retrospect and Prospect." Mercatus Center at George Mason University, Working paper 80 in Mercatus Center Working Papers

Langlois, Richard N. 2007. The Dynamics of Industrial Capitalism: Schumpeter, Chandler and the New Economy. London: Routledge.

Langlois, Richard N., and Metin Cosgel. 1993. "Frank Knight on Risk, Uncertainty, and the Firm: A New Interpretation." Economic Inquiry 31: 456-465.

Langlois, Richard N. and Nicolai J. Foss. 1999. "Capabilities and Governance: the Rebirth of Production in the Theory of Economic Organization." KYKLOS 52: 201-218.

Lazear, Edward P. 2005. “Entrepreneurship.” Journal of Labor Economics 23(4): 649-80.

Leijonhufvud, Axel. 1968. On Keynesian Economics and the Economics of Keynes: A Study in Monetary Theory. Oxford: Oxford University Press. 
Lien, Lasse B and Peter G. Klein. 2009. "Using Competition to Measure Relatedness." Journal of Management 35(4): 1078-107.

Lien, Lasse B., and Peter G. Klein. 2011. "Can the Survivor Principle Survive Diversification?"

Loasby, Brian J. 1976. Choice, Complexity, and Ignorance. Cambridge: Cambridge University Press.

Loasby, Brian J. 1982. "The Entrepreneur in Economic Theory." Scottish Journal of Political Economy 29(3): 2-23.

Loasby, Brian J. 1991. Equilibrium and Evolution: An Exploration of Connecting Principles in Economics, Manchester University Press.

Machlup, Fritz. 1967. "Theories of the Firm: Marginalist, Behavioral, Managerial.” American Economic Review 57(1): $1-33$.

Mäki, Uskali. 2001. The way the world works. In: Mäki, Uskali. (ed.) The economics world view: studies in the Ontology of Economics. Cambridge : Cambridge University Press.

Mäki, Uskali. 1992. "On the Method of Isolation in Economics." Poznan Studies in the Philosophy of the Sciences and the Humanities 26: 19-54.

Mäki, Uskali. 1994. "Isolation, Idealization and Truth in Economics." Poznan Studies in the Philosophy of the Sciences and the Humanities 38: 147-68.

Mäki, Uskali. 1994. "Reorienting the Assumptions Issue." In New Directions in Economic Methodology, ed. R. Backhouse, 237-56. London: Routledge.

Makowski, Louis, and Joseph M. Ostroy. 2001. "Perfect Competition and the Creativity of the Market." Journal of Economic Literature 39(2): 479-535.

Marchal, Jean. 1951. "The Construction of a New Theory of Profit." American Economic Review 41(4): 549-565.

Marschak, J., and Roy Radner. 1972. The Economic Theory of Teams. New Haven: Cowles Foundation and Yale University Press.

Marshall, Alfred. 1890. Principles of Economics. New York: Macmillan and Co.

Matsusaka, John G. 2001. "Corporate Diversification, Value Maximization, and Organizational Capabilities." Journal of Business 74: 409-431.

Mayer, Kyle J., and Nicholas S. Argyres. 2004. "Learning to Contract: Evidence from the Personal Computer Industry." Organization Science 15(4): 394-410.

Milgrom, Paul, and John Roberts. 1992. Economics, Organization, and Management. Prentice-Hall.

Mises, Ludwig von. 1912. The Theory of Money and Credit. New Haven: Yale University Press, 1953

Mises, Ludwig von. 1920. "Economic Calculation in the Socialist Commonwealth." In F. A. Hayek, ed., Collectivist Economic Planning. London: Routledge and Sons, 1935.

Mises, Ludwig von. 1922. Socialism: An Economic and Sociological Analysis. New Haven: Yale University Press, 1951.

Mises, Ludwig von. 1944. Bureaucracy, New Haven: Yale University Press.

Mises, Ludwig von. 1949. Human Action: A Treatise on Economics. New Haven: Yale University Press.

Mosakowski, Elaine. 1998. "Entrepreneurial Resources, Organizational Choices, and Competitive Outcomes." Organization Science 9: 625-43.

Nickerson, Jackson and Todd R. Zenger. 2004. "A Knowledge-based Theory of the Firm: The Problem-Solving Perspective." Organization Science 15(6): 617-32.

O'Brien, Dennis. 1984. "The Evolution of the Theory of the Firm." In idem., Methodology, Money and the Theory of the Firm, Vol. 1. Aldershott, UK.: Edward Elgar, 1994.

O'Driscoll, Gerald P. and Mario Rizzo. 1985. The Economics of Time and Ignorance. Oxford: Basil Blackwell. 
Osterloh, Margit and Bruno S. Frey. 2000. "Motivation, Knowledge Transfer, and Organizational Forms." Organization Science 11(5): 538-550.

Penrose, Edith T. 1959. The Theory of the Growth of the Firm. Oxford: Blackwell.

Phelps, Edmund P. 2006. "Further Steps to a Theory of Innovation and Growth - On the Path Begun by Knight, Hayek, and Polanyí." Paper for the 2006 ASSA meetings.

Pigou, Arthur C. 1928. “An Analysis of Supply.” Economic Journal 38: 238-57.

Radner, Roy. 1968. Competitive Equilibrium under uncertainty, Econometrica, 36, 31-58

Ricardo, David. 1817. Principles of Political Economy and Taxation. London: John Murray.

Robbins, Lionel C. 1932. An Essay on the Nature and Significance of Economic Science. London: Macmillan and Co.

Robinson, Joan. 1933. The Economics of Imperfect Competition. London: Routledge and Kegan Paul

Robinson, Joan. 1934. "What is Perfect Competition?," The Quarterly Journal of Economics, 49: 104-20.

Ross, Stephen A. 1973. "The Economic Theory of Agency: The Principal's Problem," The American Economic Review 63 (Papers and Proceedings): 134-39.

Rothbard, Murray N. 1962. Man, Economy, and State: A Treatise on Economic Principles. Princeton, N.J.: Van Nostrand.

Salerno, Joseph T. 2009. "Introduction to the Second Edition." In Murray N. Rothbard, Man, Economy, and State with Power and Market, second edition. Auburn, Ala.: Ludwig von Mises Institute: xix-1.

Saussier, Stéphane. 2000. "Transaction Costs and Contractual Incompleteness: The Case of Électricité De France." Journal of Economic Behavior and Organization 42(2): 189-206.

Schumpeter, Joseph A. 1911. The Theory of Economic Development. Cambridge, Mass.: Harvard University Press, 1934.

Schumpeter, Joseph A. 1939. Business Cycles: A Theoretical, Historical and statistical Analysis of the Capitalist Process. New York: McGraw-Hill.Schumpeter, Joseph A. 1942. Capitalism, Socialism, and Democracy. New York: Harper and Row.

Schumpeter, Joseph A. 1954. History of Economic Analysis. Cambridge, Mass.: Harvard University Press.

Segal, Gary; Dan Borgia and Jerry Schoenfeld. 2005. "The Motivation to Become an Entrepreneur." International Journal of Entrepreneurial Behaviour and Research 11(1): 42-57.

Shackle, George L.S. 1972. Epistemics and Economics. Cambridge: Cambridge University Press.

Simon, Herbert A. 1973. "The Structure of Ill Structured Problems 1.” Artificial intelligence 4(3-4): 181-201.

Simon, Herbert A. 1991. "Organizations and Markets." The Journal of Economic Perspectives 5(2): 25-44.

Spulber, Daniel F. 2009. The Theory of the Firm: Microeconomics with Endogenous Entrepreneurs, Firms, Markets, and Organizations. Cambridge: Cambridge University Press.

Stenmark, Dick. 2000. "Leveraging Tacit Organizational Knowledge.” Journal of Management Information Systems 17(3): 9-24.

Taussig, Frank W. 1911. Principles of Economics. London: Macmillan.

Viner, Jacob. 1931. "Costs Curves and Supply Curve," Zeitschrift für Nationalökonomie, 3: 23-46.

Wernerfelt, Birger. 1994. "An Efficiency Criterion for Marketing Design.” Journal of Marketing Research. 31(4): $462-70$.

Wicksteed, Philip H. 1910. The Common Sense of Political Economy. London: Macmillan and Co.

Williamson, Oliver E. 1971. "The Vertical Integration of Production: Market Failure Considerations." American Economic Review 61: 112-23. 
Williamson, Oliver E. 1975. Markets and Hierarchies: Analysis and Antitrust Implications. New York: Free Press.

Williamson, Oliver E. 1985. The Economic Institutions of Capitalism. New York: Free Press.

Williamson, Oliver E. 1988. “The Logic of Economic Organization.” Journal of Law, Economics, and Organization 4(1): 65-93.

Williamson, Oliver E. 1991b. "Economic Institutions: Spontaneous and Intentional Governance." Journal of Law, Economics, and Organization 7: 159-87.

Williamson, O liver E. 1996. The Mechanisms of Governance. Oxford: Oxford University Press.

Williamson, Oliver E. 2000. "The New Institutional Economics: Taking Stock, Looking Ahead." Journal of Economic Literature 38(3): 595-613.

Winter, Sidney G. 1988. "On Coase, Competence, and the Corporation." Journal of Law, Economics, and Organization 4(1): 163-80.

Witt, Ulrich. 1998a. "Imagination and Leadership: the Neglected Dimensions of an Evolutionary Theory of the Firm." Journal of Economic Behavior and Organization 35: 161-77.

Witt, Ulrich. 1998b. “Do Entrepreneurs Need Firms?” Review of Austrian Economics 11: 99-109.

Witt, Ulrich. 2007. "Firms as Realizations of Entrepreneurial Visions." Journal of Management Studies 44(7): 1125-140.

Van Zandt, David E. 1993. "The Lessons of the Lighthouse: 'Government' or 'Private' Provision of Goods." Journal of Legal Studies 22(1): 47-72. 


\section{COORDINATION}

Profa. Dra. Maria Sylvia Macchione Saes

Prof. Dr. Decio Zylbersztajn

Profa. Dra. Roberta de Castro Souza

Profa. Dra. Vivian Lara dos Santos Silva

\section{ORGANIZING ASSISTANTS}

Bruna Liria Avelhan

Gabriela Feresin Jardim

Leandro Simões Pongeluppe

Kassia Watanabe

Nobuiuki Costa Ito

Paula Sarita Bigio Schnaider

Support

Nice Santana 